\title{
Dendroindication
}

\section{of Retrospective Larch Defoliation}

\author{
Tatyana I. Morozova and Viktor I. Voronin* \\ Siberian Institute of Plant Physiology \\ and Biochemistry SB RAS \\ 123 Lermontov Str., Irkutsk, 664033, Russia
}

Received 08.07.2016, received in revised form 04.10.2016, accepted 04.04.2018, published online 19.04.2018

We propose a method for dating of growth seasons of Siberian larch (Larix sibirica Ledeb.) following insect infestation events and defoliation. Needle damage during the growth phase triggers tree investment into additional growth of brachyblasts within the same season. Dissecting brachyblasts allows the identification of these secondary growth events. We tested this method in the Baikal region, East Siberia, in larch forest sites infested by the gypsy moth (Lymantria dispar L.) from 1997 to 2000. Defoliation of trees due to the infestation was highest in 1997 (63\%) and decreased gradually to $46 \%$ in 1998, 50\% in 1999 and 35\% in 2000. During the period of the Lymantria dispar outbreak some brachyblasts had needles reduced by four times after defoliation. The proposed method allows retrospective identification of years of larch canopy damage and defoliation not only by insects, but also fungi or toxic gases in the case of early summer and summer defoliation. Wintering buds are already formed during this period, so defoliation and elimination of its inhibiting impact (power) on the growth of wintering buds results in their fast regeneration.

Keywords: Siberian larch, defoliation, radial and brachiblasts increment.

Citation: Morozova T.I., Voronin V.I. Dendroindication of retrospective larch defoliation. J. Sib. Fed. Univ. Biol., 2018, 11(3), 275-284. DOI: 0.17516/1997-1389-0049.

(C) Siberian Federal University. All rights reserved

This work is licensed under a Creative Commons Attribution-NonCommercial 4.0 International License (CC BY-NC 4.0).

* Corresponding author E-mail address: bioin@sifibr.irk.ru 


\title{
Ретроспективная дендроиндикация периодов дефолиации лиственницы
}

\author{
Т.И. Морозова, В.И. Воронин \\ Сибирский институт физиологии \\ и биохимии растений СО РАН
}

Россия, 664033, Иркутск, ул. Лермонтова, 123

\begin{abstract}
Предложен новый метод датировки периодов дефолиаџии сибирской лиственниць (Larix sibirica Ledeb.) насекомыми, более точный по сравнению с дендрохронологическим. Повреждение кроны лиственницы во время периода роста вызывает дополнительный прирост брахибластов в течение одного вегетациионого периода. На продольном срезе брахибласта можно довольно легко идентифицировать эти дополнительные сезонные приросты. Мы апробировали этот метод в Прибайкалье (Восточная Сибирь) в лиственничниках, поражавшихся непарным шелкопрядом (Lymantria dispar L.) с 1997 по 2000 г2. Дефолиаџия деревьев этим вредителем была самой высокой в 1997 2. (62 \%) и постепенно уменьшалась до $51 \%$ в 1998 2., $46 \%$ \% 1999 г. и $36 \%$ в 2000 2. В период вспьики размножения непарного шелкопряда некоторые брахибласты имели по четыре удвоенных сезонных прироста, что свидетельствует о четырехкратном возобновлении хвои после дефолиации. Предложенный метод позволяет производить ретроспективную идентификацию периодов повреждения кронь лиственниць не только насекомыми, но также микромицетами и токсичными газами в случае раннелетней и летней дефолиации. Зимующчие почки лиственницы уже сформированы в течение этого периода, поэтому дефолиация и ликвидация ингибирующего воздействия на их рост приводит к появлению ещзе одного сезонного прироста.
\end{abstract}

Ключевые слова: лиственница сибирская, дефолиация, радиальный прирост, брахибласты.

\section{Introduction}

Gypsy moth (Lymantria dispar L.: Lepidoptera: Erebidae) is one of the most serious defoliating forest pests forming extensive and devastating outbreaks in the northern hemisphere (Staudt and Lhoutellier, 2007; Mcewan et al., 2009). The periodicity of outbreaks and the area of infested forests can vary significantly. Trees at the forest-steppe ecotone in the semiarid northeastern Asia are regularly subject to gypsy moth outbreaks (Gninenko and Orlinskii, 2003). Since the forest-steppe ecotone in southern Siberia, Kazakhstan, and Mongolia forms the southern, presumably drought-induced limit of the Siberian taiga (Gunin et al., 1999; Dulamsuren et al., 2009), any additional stressor could be highly relevant for the spatiotemporal vegetation dynamics of the forest-steppe ecotone (Dulamsuren et al., 2010).

The main host of $L$. dispar in Eastern Siberia (the region in which this study was conducted) is silver birch, Betula pendula Roth. Older larvae feed on several species of coniferous trees that younger larvae avoid, including larch and pine (Rozhkov and Vasilyeva, 1982; Baranchikov, 1989).

The effects of defoliation depend primarily on the amount of foliage destructed, the condition 
of the tree at the time of defoliation, the number of consecutive defoliations, available soil moisture, and the host species. If less than $50 \%$ of their crown is defoliated, most deciduous trees will experience only a slight reduction (or loss) in radial growth. If more than $50 \%$ is defoliated, most hardwoods will refoliate or produce a second flush of foliage by midsummer. Healthy trees can usually withstand one or two consecutive defoliations of greater than $50 \%$. Trees that have been weakened by previous defoliation or been subjected to other stresses such as droughts are frequently killed after a single defoliation of more than 50\% (Rozhkov and Vasilyeva, 1982; Rozhkov et al., 1991).

Trees use energy reserves during refoliation and are eventually weakened. Weakened trees exhibit symptoms such as dying back of twigs and branches in the upper crown and sprouting of old buds on the trunk and larger branches. Weakened trees experience radial growth reduction of approximately 30 to 50 percent. Trees weakened by consecutive defoliations are also vulnerable to attack by disease organisms and other insects (McManus et al., 1992).

Various methods exist to retrospectively study foliage status in conifers. Most frequently these methods rely on the use of radial tree increment as an indicator. Reductions in treering width following gypsy moth infestations have been previously shown for several tree species (Muzika and Liebhold, 2001; Naidoo and Lechowicz, 2001), as well as for larch trees infested by other insect species (Baltensweiler et al., 1977; Baltensweiler et al., 2008; Buentgen et al., 2009). We successfully applied this method to study defoliation of larch forests (Larix sibirica Ledeb.) in Eastern Siberia by Zeiraphera griseana Hbn and Erannis jacobsoni Djak (Pleshanov et al., 1991).

In the beginning of the 1990s, the new needle trace method (NTM), a method for the retrospective assessment of needle retention on pine trees, was developed (Kurkela and Jalkanen, 1990). Analysis of covariance conducted as part of the NTM showed that logarithmically transformed needle density and the average age of attached needles had the highest significant negative correlation with radial and height increments both in the period prior to the defoliation and at the time when trees suffered defoliation. Relationships between height increment and the number of needles and needle loss were positive and significant. NTM allows quantifying longterm variation in needle retention on a single tree. It has been used for revealing past needlecast epidemic (Jalkanen et al., 1994a) and a longterm negative impact of air pollution on needle retention (Jalkanen, 1996). Additionally, the NTM has produced the chronology of needle retention in two pine stands in England (Jalkanen et al., 1994b) and in numerous stands in northern and southern Finland (Jalkanen et al., 1995). Foliage status in the main stem of Scots pines (Pinus sylvestris L.) in Finland was studied retrospectively by applying the NTM to a stand seriously defoliated by the pine sawfly (Diprion pini L.) in the 1980s (Kurkela et al., 2005).

We suggest a method of retrospective direct determination of larch tree defoliation caused by insect attacks, which is not based on radial increment but relies on seasonal brachyblast growth (Morozova et al., 2010). It does not require complicated statistics.

A brachyblast is a densely crowded short axillary branchlet or shoot of limited growth, in which internodes elongate little if not at all. It bears reproductive structures and/or leaves and is also known as a spur. It is a typical structure of gymnosperms, but it can also be found in several angiosperm families (Dylis, 1958). Larch brachyblasts undergo two development stages (Rozhkov et al., 1991). Seedlings of the current year develop a growth bud, which transforms to 


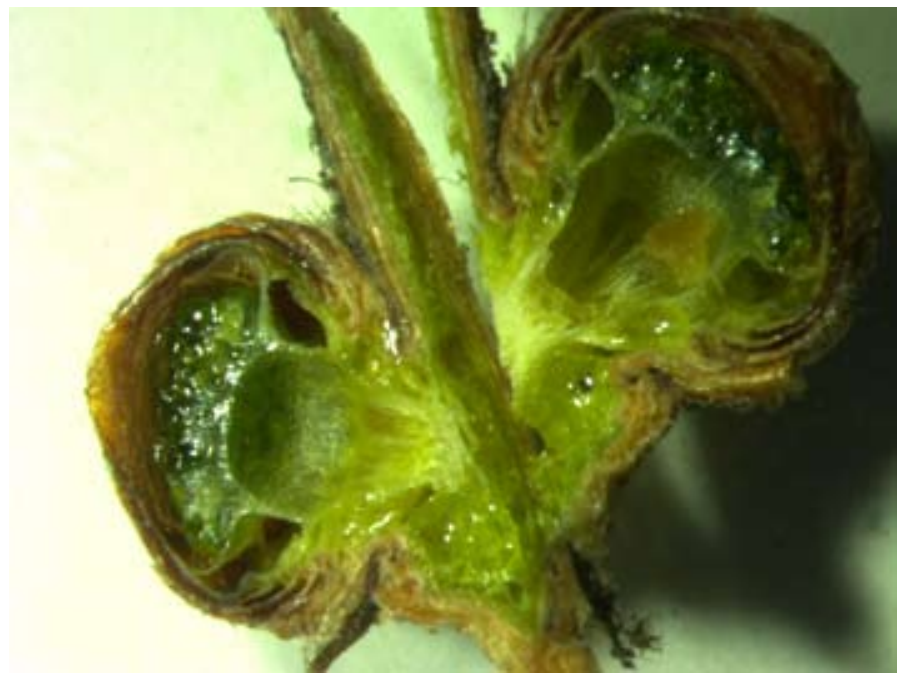

Fig. 1. Primary growth bud of Siberian larch in May 2015. Clearly visible are two resin receptacles

a real brachyblast the following year. It bears a wintering bud on the apical part by the end of the vegetation season. Along the central axis of the primary growth bud there is a cavity with a resin receptacle on either side (Fig. 1). Brachyblast forms these structures in an annual increment.

\section{Materials and methods}

In September 2001 we collected 30-60-yearold larch trees in larch (Larix sibrica) forest stands infested by the gypsy moth $L$. dispar from 1997 to 2000 in the Baikal region, East Siberia

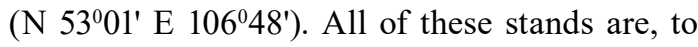
some extent, in the forest-steppe ecotone. This part of the Baikal region is characterized as the sub-boreal dry type of zonality due to increased aridity of climate caused by the rain shadow effect from local mountain systems (Sizykh and Voronin, 2013).

A test plot containing 50 trees was set up in one of these stands in 1997 infested by the gypsy moth. All trees were marked to allow visual monitoring of defoliation during the 1997-2000 period. In September 2001 we sampled branches from the middle part of the crown of the first order from 12 trees and conducted histological analysis of brachyblasts on 2-5 year old shoots (100-150 pieces for each tree). Trees use energy reserves during refoliation and become eventually weakened and exhibit symptoms such as dieback of twigs and branches in the upper crown and sprouting of old buds on the trunk and larger branches. Branches of the middle part of the crown are more robust.

Brachyblasts were brought to the laboratory as air-dried condition. Cross sections of larch brachyblasts were obtained using a medical scalpel. Annual increments of brachyblasts were measured under the microscope MBS-10 (x40) (LOMO-Optic, Leningrad, USSR). More than 2,000 brachyblasts from 12 trees were analyzed.

Boundaries of each seasonal increment of the brachyblast are fairly easily identified by the remains of additional edge needles, which are derivatives of internal bud chaffs not casting together with true needles (Rozhkov et al., 1991). The remains of these needles form specific border-line rings separating one seasonal increment from the other on the external surface of the brachyblast. However, when the number of seasonal increments exceeds ten, the external boundary of seasonal increment becomes 


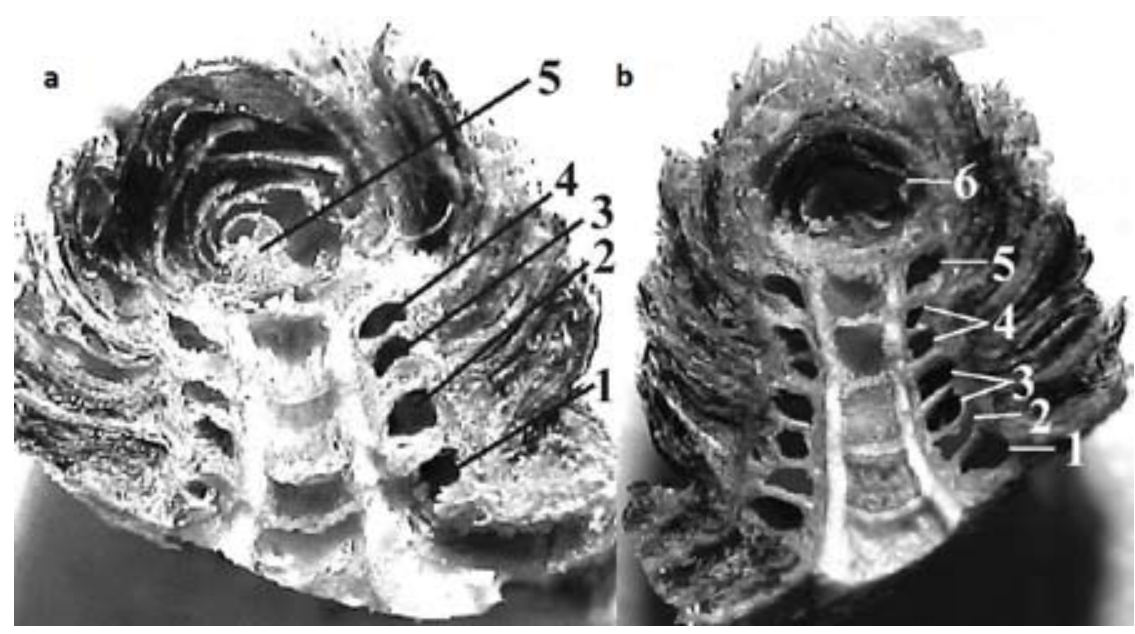

Fig. 2. Cross sections of Siberian larch brachyblasts removed on April 2001. A - unaffected four year old brachyblast. Resin receptacles formed: 1 - in 1998, 2 - in 1999, 3 - in 2000, 4 - in 2001, 5 - wintering bud. B five year old brachyblast after two defoliations. Resin receptacles formed: 1 - in 1997, 2 - in 1998, 3-in 1999, 4 - in 2000, 5 - in 2001, 6 - wintering bud

indistinct and their identification inaccurate. In this case boundaries may only be identified on horizontal cross-sections of brachyblasts (Fig. 2).

The brachyblast stalk has distinct cavities, compartments of bud growth separated by cross-walls and representing annual increments. The brachyblast stalk is surrounded by resin receptacles confined by similar cross-walls.

In an undamaged brachyblast the number of receptacle cross-walls corresponds to the number of cross-walls in the brachyblast stalk, whereas defoliation during the growth season results in an extra cross-wall in receptacles. Additionally, there is one set of remains of additional edge needles between covering scales. Figure $2 b$ shows that both in 1999 and 2000 the brachyblast formed two seasonal increments revealing defoliation during those growth periods. Larch defoliation is dated by identifying differences between the number of resin receptacles of brachyblasts and the age of the first order branch shoot, where brachyblasts are located. Preliminary assessment of annual cross-walls of the brachyblast stalk and resin receptacles is done in the field by using a magnifying glass.
Increment cores, collected with an increment borer, were sampled from larch trees in September 2004. Tree-ring width was measured with a precision of $10 \mu \mathrm{m}$ using a movable object table, which movements are electronically transmitted to a computer system equipped with TSAP-Win software (Rinntech, Heidelberg, Germany). Evaluation age trend held for each individual tree age approximated negative exponential curve, which is calculated with respect to the indices of tree-ring width (Methods of dendrochronology, 1990).

\section{Results and discussion}

The study area was infested at different times by various dendrophilous species such as Z. griseana, Dasychira abietis Schiff., Maera anastomosis L., and Leucoma salicis L. The outbreak areas are vast and damage inflicted generally does not cause tree mortality. The tree ring curves on Fig. 3 shows that Z. griseana outbreaks were in these forest-steppe zone: in 1958, 1961, 1966, 1971, 1975, 1978, 1981, 1987 (Pleshanov et al., 1991) and 1988, 1991, 1995. The increment decline following each defoliation was 


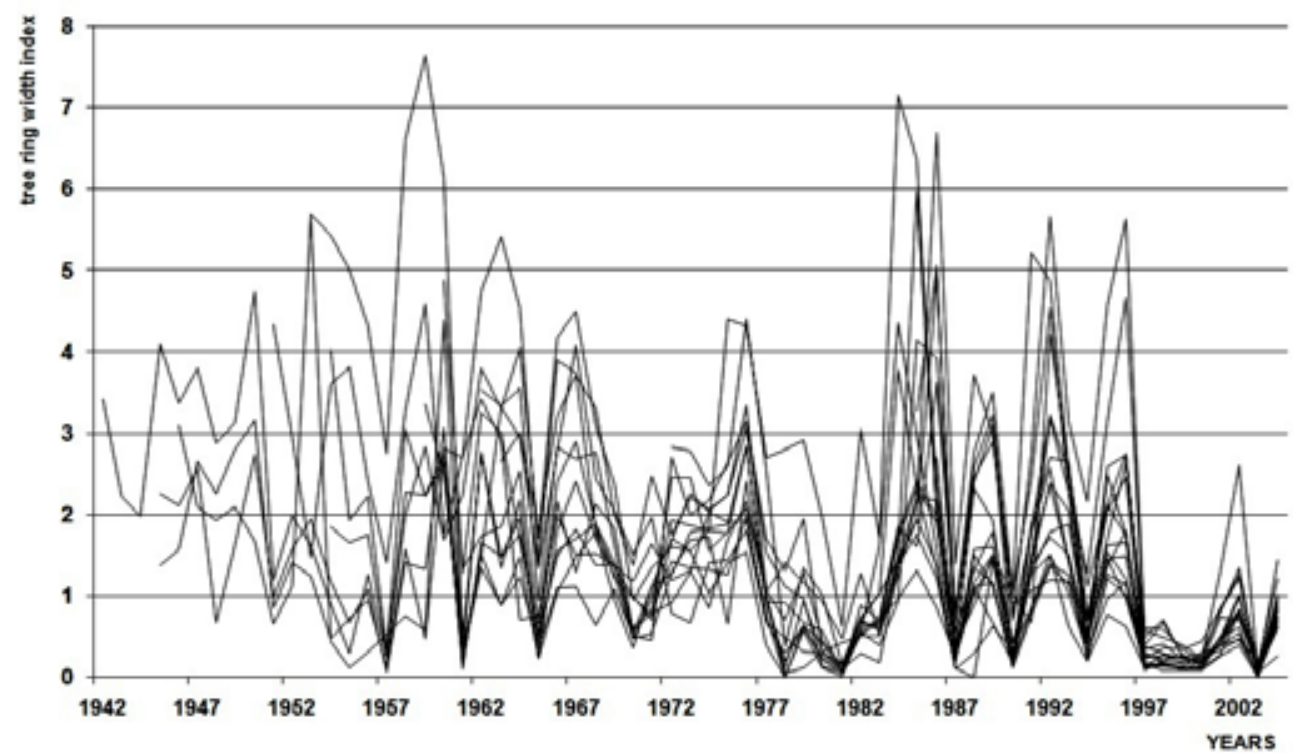

Fig. 3. Tree-ring chronologies of the larch forest sites infected by the gypsy moth from 1997 to 2000

recorded over only 1 to 2 years. The same stand was also damaged by E. jacobsoni in 1964 and 1971 (Pleshanov et al., 1991). The consequences of that insect defoliation were registered over 5 years.

From 1997 to 2000 larch forest sites was infested by the gypsy moth (L. dispar). The mean defoliation of trees caused by gypsy moth was highest in 1997 (63\%) and gradually decreased to $46 \%$ in $1998,50 \%$ in 1999 , and $35 \%$ in 2000 . The outbreak in the study area ceased in 2001. Tree-ring curves (Fig. 3) demonstrate defoliation of larch trees by gypsy moth during the growing seasons of 1997-2000 resulted in the formation of narrow rings in these four years. More detailed information on defoliation of trees can be obtained by analyses of annual increment of brachyblasts from larch forest sites infested by $L$. dispar. A distinct feature of Siberian larch is the ability to produce new needles after defoliation (Vasil'yeva and Pleshanov, 1975). New needles can develop from the already formed wintering buds - the brachyblasts - in response to defoliation during the growing period caused by insects, phytopathogenic fungi, or toxic gases (Pleshanov, 1982). Triggering the development of new needles from brachyblasts produces two seasonal increments in the year of damage, similar to the formation of a false growth ring in the year of crown damage. Formation of two annual increments in brachyblasts may take place during several succeeding years, which make three year old brachyblasts appear as six year olds if calculated from their number of increments. Frequent defoliation and related secondary formation of needles provoke early degeneration of brachyblasts (Gunin et al., 1999).

The results of the analysis of brachyblast seasonal increments for 12 trees show that in the fourth year of repeated defoliation the number of brachyblasts in all trees decreased. This is a direct consequence of reducing the length of auxiblasts (McManus et al., 1992). Unfortunately, we had not measured the length of auxiblasts. At the same time trees are known to respond to defoliation quite differentially. An old growth tree shows less ability to regenerate its needles after defoliation by caterpillars of $L$. dispar. The 
Table 1. Number of brachyblasts (numerator) with a variable amount of seasonal increments (denominator) on larch shoots of different age in a gypsy moth infestation focus

\begin{tabular}{|c|c|c|c|c|}
\hline \multirow{2}{*}{ Tree No./Tree age } & \multicolumn{4}{|c|}{ Shoot age, (formation year) } \\
\hline & $2(2000)$ & 3 (1999) & $4(1998)$ & $5(1997)$ \\
\hline $1 / 42$ & $\begin{array}{c}+16 / 1 \\
- \\
\odot 20 / 2\end{array}$ & $\begin{array}{c}- \\
* 13 / 4 ; 6 / 5 \\
\odot 15 / 3\end{array}$ & $\begin{array}{c}\dagger 10 / 3 \\
* 16 / 5 ; 12 / 6 ; 15 / 7 ; 1 / 8 \\
\odot 5 / 4\end{array}$ & $\begin{array}{c}\dagger 5 / 4 \\
* 7 / 6 ; 10 / 7 ; 14 / 8 ; 1 / 9 \\
\odot 8 / 5\end{array}$ \\
\hline $\begin{array}{l}\text { total number of brachyblasts/ } \\
\text { defoliation } \%\end{array}$ & $36 / 40$ & $34 / 50$ & $59 / 50$ & $45 / 80$ \\
\hline $12 / 62$ & $\begin{array}{c}+29 / 1 \\
- \\
+26 / 2\end{array}$ & $\begin{array}{c}+4 / 1 ; 33 / 2 \\
- \\
\odot 10 / 3\end{array}$ & $\begin{array}{c}+1 / 1 ; 9 / 2 ; 26 / 3 \\
- \\
-7 / 4\end{array}$ & $\begin{array}{c}+5 / 2 ; 7 / 3 ; 19 / 4 \\
- \\
\odot 10 / 5\end{array}$ \\
\hline $\begin{array}{l}\text { total number of brachyblasts/ } \\
\text { defoliation } \%\end{array}$ & $55 / 50$ & $47 / 20$ & $43 / 30$ & $41 / 75$ \\
\hline
\end{tabular}

†perished brachyblasts; *damaged brachyblasts; $;$ undamaged brachyblasts.

degree of defoliation also plays an important role.

To illustrate our points further, we consider more detailed data for trees 1 and 12 (Table 1). Tree 1 (42 y.o.) had a small portion of brachyblasts unaffected with the number of annual increments corresponding to the shoot age. The majority of brachyblasts was repeatedly defoliated. For instance, one brachyblast (1/9), which appeared in 1997, restored needles four times after being browsed by gypsy moth larvae (i.e. 5 annual increments +4 extra increments caused by browsing during the growing season). High needle regeneration ability of this tree prevented massive death of brachyblasts. Tree 12 (62 y.o.) had a greater number of its brachyblasts (47) perished on shoots after the first defoliation. They formed only a two-season increment. This tree also had a high number of dead growth buds formed only at one-season increment (34). This tree was either more heavily browsed by insects than tree 1 or its ability to develop secondary needles was lower. It had the largest number of perished brachyblasts and growth buds among the 12 trees examined. In 2000 the branches of this tree formed 55 brachyblasts, less than a half of which survived.
In general, investigated trees indicated to have undergone massive damage in 1997-1998. Mean defoliation of trees by gypsy moth was highest in 1997 (63\%) and gradually decreased to $35 \%$ in 2000 (Fig. 4). The amount of perished brachyblasts varied from $13 \%$ in tree 2 and tree 7 to up to $70 \%$ in tree 12 . The average parameter for 12 trees equaled $37 \%$. Most one year old brachyblasts perished in the last year of gypsy moth infestation in 2000. By this time the trees had apparently been significantly oppressed, which exhausted their recovery abilities (Fig. 4).

Our study suggests the possibility of identifying only the duration of the development of pathogen of focus or defoliation years dependent on the damaging agent but identification of the degree of plantation defoliation was not considered. We consider that it is sufficient to select 5-6 first order branches in the middle part of the crown of 10 trees in order to obtain reliable results forming undamaged, damaged and perished brachyblasts after defoliation in different years. For example, in the gypsy moth case we selected branches from 12 trees of the first stratum. These branches had no external signs of stem damage (fire scars, etc.). The time period for which the years of larch defoliation 


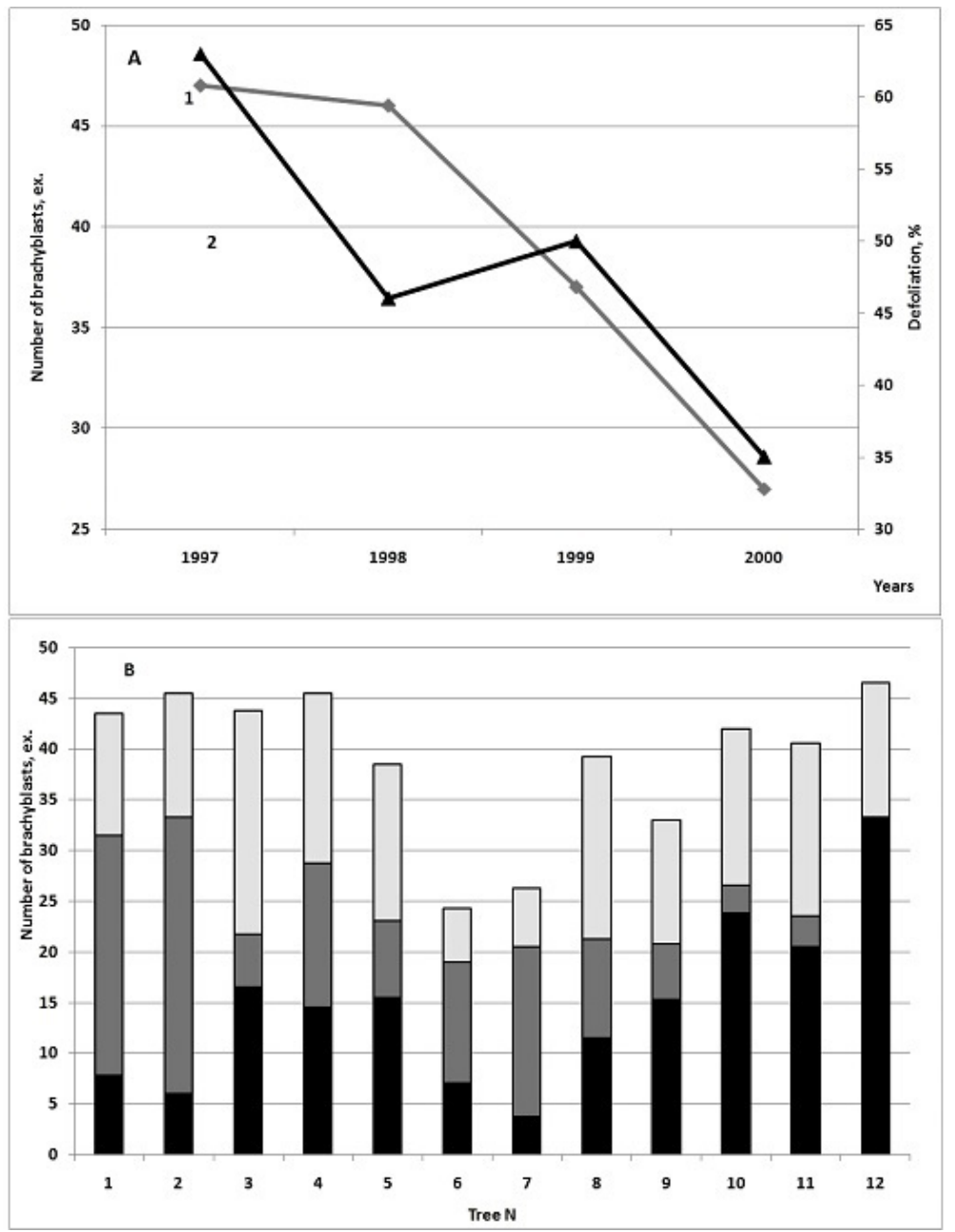

Fig. 4. Dynamic of total brachyblasts number (1) and defoliation (2) from 1997 to 2000 (average value for 12 trees) (A) and the mean numbers of undamaged (light gray), damaged (gray) and perished (black) brachyblasts in same time for each tree (B)

can be identified depends on the brachyblasts' life cycle. Despite the evidence that their life cycle may reach 40 years (Rozhkov et al., 1991; Dylis, 1958), our research suggests 20 years for which a distinct identification of the number of seasonal increments of brachyblasts is possible.

The proposed method allows retrospective identification of the years of larch crown damage by defoliating not only from insects, but also from fungi or toxic gases in case of early summer (June) and summer (early August) defoliation. Wintering buds are already formed during this period, so defoliation and elimination of its inhibiting impact on the growth of wintering buds results in their fast regeneration.

\section{Acknowledgements}

The reported study was funded by the Russian Foundation for Basic Research according to the research project No. 17-29-05074. The study was partially supported by RFBR, research project No. 14-44-040307_siberia. We greatly acknowledge the work of Michael Müller (METLA, Finland), who improved the English grammar of the manuscript. 


\section{References}

Baltensweiler W., Benz G., Bovey P., Delucchi V. (1977) Dynamics of larch bud moth populations. Annual Reviews on Entomology, 22: 79-100

Baltensweiler W., Weber U.M., Cherubini P. (2008) Tracing the influence of larch-bud-moth insect outbreaks and weather conditions on larch tree-ring growth in Engadine (Switzerland). Oikos, 117(2): 161-172

Baranchikov Y.N. (1989) Ecological basis of the evolution of host relationships in Eurasian gypsy moth populations. Proceedings of Lymantriidae: a comparison of features of new and old world tussock moths. Wallner W.E., McManus K.A. (tech. coord.) USDA, Broomall, PA, p. 319-338

Buentgen U., Frank D., Liebhold A., Johnson D., Carrer M., Urbinati C., Grabner M., Nicolussi K., Levanic T., Esper J. (2009) Three centuries of insect outbreaks across the European Alps. New Phytologist, 182: 929-941

Dulamsuren Ch., Hauck M., Bader M., Osokhjargal D., Oyungerel Sh., Nyambayar S., Runge M., Leuschner C. (2009) Water relations and photosynthetic performance in Larix sibirica growing in the forest-steppe ecotone of northern Mongolia. Tree Physiology, 29: 99-110

Dulamsuren C., Haucka M., Leuschner H.H., Leuschner Ch. (2010) Gypsy moth-induced growth decline of Larix sibirica in a forest-steppe ecotone. Dendrochronologia, 28: 207-213

Dylis N.V. (1958) On brachyblasts origin in Larix. Doklady Akademii Nauk SSSR, 122(1): 138-141 (in Russian)

Gninenko Yu.I., Orlinskii A.D. (2003) Outbreaks of Lymantria dispar in Russian forests during the 1990s. European and Mediterranean Plant Protection Organization Bulletin, 33: 325-329

Gunin P.D., Vostokova E.A., Dorofeyuk N.I., Tarasov P.E., Black C.C. (1999) Vegetation dynamics of Mongolia. Dordrecht-Boston-London, Kluwer Academic Publishers, $235 \mathrm{p}$.

Jalkanen R., Aalto T., Kurkela T. (1994a) The use of needle-trace method (NTM) in retrospectively detecting Lophodermella needle-cast epidemic. European Journal of Forest Pathology, 24: 376-385

Jalkanen R., Aalto T., Innes J., Kurkela T., Townsend I. (1994b) Needle retention and needle loss of Scots pine in recent decades at Thetford and Alice Holt, England. Canadian Journal of Forest Research, 24: 863-867

Jalkanen R., Aalto T., Kurkela T. (1995) Development of needle retention in Scots pine (Pinus sylvestris) in 1957-1991 in northern and southern Finland. Trees, 10: 125-133

Jalkanen R. (1996) Needle retention chronology along a pollution gradient. Tree rings, environment and humanity. Dean J.S., Meko D.M., Swetnam T.W. (eds.) Radiocarbon, p. 419-426

Kurkela T., Jalkanen R. (1990) Revealing past needle retention in Pinus spp. Scandinavian Journal of Forest Research, 5: 481-485

Kurkela T., Aalto T., Varama M., Jalkanen R. (2005) Defoliation by the common pine sawfly (Diprion pini) and subsequent growth reduction in Scots pine: a retrospective approach. Silva Fennica, 39(4): 467-480

Mcewan R.W., Rieske L.K., Arthur M.A. (2009) Potential interactions between invasive woody shrubs and the gypsy moth (Lymantria dispar), an invasive insect herbivore. Biological Invasions, 11: 1053-1058

McManus M., Schneeberger N., Reardon R., Mason G. (1992) Forest Insect \& Disease Leaflet 162: Gypsy Moth. U.S. Department of Agriculture Forest Service. 
Methods of dendrochronology. Applications in the environmental sciences (1990) Cook E.R., Kairiukstis L.A. (eds.) Dordrecht - Boston - London, Kluwer Acad. Publ., 394 p.

Morozova T.I., Voronin V.I., Stepanchuk E.S. (2010) Method of definition larch defoliation on brachyblasts increment. Lesovedenie, 5: 62-64 (in Russian)

Muzika R.M., Liebhold A.M. (2001) Effects of gypsy moth defoliation in oak-pine forests in the northeastern United States. Proceedings: Integrated Management and dynamics of Forest Defoliating Insects. 1999 August 15-19. Liebhold A.M., McManus M.L., Otvos I.S., Fosbroke S.L.C. (eds.) Victoria, BC, p. $117-123$

Naidoo R., Lechowicz M.J. (2001) Effects of gypsy moth on radial growth of deciduous trees. Forest Science, 47: 338-348

Pleshanov A.S. (1982) Defoliating insects in East Siberia larch forests. Novosibirsk, Nauka, 234 p. (in Russian)

Pleshanov A.S., Voronin V.I., Khlimankova E.S., Epova V.I. (1991) Tolerance to insect defoliatiton: biocenotic aspects. Forest Insect Guilds: Patterns of Interaction with Trees. Baranchikov Y.N., Mattson W.J., Hain F.P., Payne T.L. (eds.) U.S. Dep. Agric. For. Serv. Gen. Tech. Rep. NE-153, p. 211212

Rozhkov A.S., Khlimankova E.S., Stepanchuk E.S. (1991) Restoration processes in conifers during defoliation. Novosibirsk, Nauka, 86 p. (in Russian)

Rozhkov A.S., Vasilyeva T.G. (1982) Gypsy moth in Eastern Siberia. Gypsy moth in Middle and Eastern Siberia. Novosibirsk, Nauka, p. 4-19 (in Russian)

Sizykh A.P., Voronin V.I. (2013) Spatial variability of vegetation in the changing climate of the Baikal region. Current progress in biological research. Croatia, InTech, p. 149-168

Staudt M., Lhoutellier L. (2007) Volatile organic compound emission from holm oak infested by gypsy moth larvae: evidence for distinct responses in damaged and undamaged leaves. Tree Physiology, 27: $1433-1440$

Vasil'yeva T.G., Pleshanov A.S. (1975) Physiology of larch oppression and die-back in Jackobson's geometrid moth foci. Impact of anthropogenic and natural factors on conifers. Irkutsk, p. 179-214 (in Russian) 